\title{
CORPORATE GOVERNANCE
}

\section{CORPORATE GOVERNANCE STRUCTURE AND SHAREHOLDER WEALTH MAXIMIZATION}

\section{KWadwo Boateng Prempeh ${ }^{1}$,} EUGENE ODARTEI-MiLLS ${ }^{2}$

\author{
${ }^{1}$ Sunyani Polytechnic, Sunyani, Ghana \\ ${ }^{2}$ Sahel Sahara Bank, Achimota, Ghana
}

Jel Classifications: G30, G32

KEYWORDS: Corporate governance, shareholder wealth, dividend, wealth maximization, Ghana Stock Exchange

\begin{abstract}
Over the past two decades the ideology of shareholder value has become entrenched as a principle of corporate governance among companies. A well-established corporate governance system suggests effective control and accounting systems, stringent monitoring, effective regulatory mechanism and efficient utilization of firms' resources resulting in improved performance. The object of the research presented in this paper is to provide empirical evidence on the effects of corporate governance on shareholder value maximization of the listed companies in Ghana. Data from ten companies listed on Ghana Stock Exchange covering the period 2003-2007 were used and analysis done within the panel data framework. The dependent variables, dividend per share and dividend yield are used as a measure of shareholder wealth maximization and the relation between corporate governance and shareholder wealth maximization is investigated.
\end{abstract}

The regression results show that both the board size and the independence have statistically significant relationship with shareholder wealth maximization.

Source: Prempeh K.B., Odartei-Mills E., 2015. "Corporate governance structure and shareholder wealth maximization", Perspectives of Innovations, Economics \& Business, Vol.15(1), pp.1-30,

http://dx.doi.org/10.15208/pieb.2015.01

\section{Introduction}

Over the past two decades the ideology of shareholder value has become entrenched as a principle of corporate governance among companies based in the United States and Britain (Lazonick and O'Sullivan, 2000). Over the past two or three years, the rhetoric of shareholder value has become prominent in the corporate governance debates in European nations such as Germany, France and Sweden. Within the past year, the arguments for "maximizing shareholder value" have even achieved prominence in Japan (Lazonick and O'Sullivan, 2000). In Africa, corporate governance has been receiving some attention in recent years, partly due to the poor performance of corporate institutions (Berglof and von Thadden, 1999). In 1999, the OECD issued a document, The OECD Principles of Corporate Governance that emphasize that corporations should be run or manage, first and foremost, in the interests of shareholders (OECD 1999).

Corporate governance is concerned with the processes and structures through which members interested in the overall well-being of the firm take measures to protect the 
interests of the stakeholders (Ehikioya, 2009). Good corporate governance is centered on the principles of accountability, transparency, fairness and responsibility in the management of the firm. The institution of corporate governance in a firm is an attempt to ensure the separation of ownership and control, and this often results in principal-agent problems (Jensen and Meckling, 1976). Agency theory explains the conflict of interests between the shareholders and managers. The separation of ownership and control has been one of the most contentious issues in the financial literature.

One of the important elements of the corporate governance that has received attention and undergone reforms is the structure of the board of directors (Abdullah, 2004). A board of directors is viewed as a team of individuals with fiduciary responsibilities of leading and directing a firm, with the primary objective of protecting the firm's shareholders' interests. Thus, a board of directors is responsible in setting the corporate goals, which aim at realizing long-term shareholders' value. The board is responsible for evaluating the appropriateness of the strategies and approaches taken by the management in translating the corporate goals. To ensure an effective implementation of the strategies, the board should monitor closely the progress by reviewing carefully the performance of the management, for the purpose of giving rewards or punishment to the management. The board's success in discharging its fiduciary duties and, in working closely with the management, would be predicted to increase the wealth of the shareholders.

The creation of a board of directors is to monitor the performance of the firms so that the interests of the shareholders are protected. It is therefore predicted that if the board performs its duties effectively, the value of the firms is predicted to increase and the wealth of the shareholders will be enhanced accordingly.

Scholars of corporate governance, starting from Ross (1973) and Fama (1980), have been concerned as to how to address the principal-agent problem, which arises from the separation of ownership and control. The recent financial turmoil in Asia in the late 1990s and high profile scandals in Enron, WorldCom and other related companies has again stimulated policy makers, investors, academics and other stakeholders, both in the public and private sectors, to take interest in the campaign for good corporate governance. The challenges from these recent events have necessitated the taking of various measures across the globe. These measures, such as the SarbanesOxley Act of 2002, regulate the system to ensure adherence to principles of good corporate governance (Aguilera, 2005).

In Africa, corporate governance has been receiving some attention in recent years, partly due to the poor performance of corporate Africa (Berglof and von Thadden, 1999). The establishment of an Institute of Directors (IoD) combined with such other arrangements and mechanisms as the existing Companies Codes in individual countries, stock market listing rules and regulations and Securities and Exchange Commission in individual countries provide basic channels through which corporate governance issues are addressed. Issues surrounding disclosure, employee and investor protection, corporate social responsibility, insider trading, related party transactions, matters dealing with the responsibilities and privileges of boards of directors are in these documents (Kyereboah-Coleman, 2007a).

Shareholder wealth or value maximization is a long-term decision and its success largely depends on solid value-based management practice. Scholars such as Brealey and Myers (2002), agree that shareholder wealth maximization should be the overall goal of every corporate entity. Maximization of shareholders' wealth ensures that shareholders are adequately compensated for risk undertaken (Dufrene and Wong, 1996). Shareholder wealth is the total benefit to shareholders from investing in a company. 
Price Waterhouse Coopers (2006) mentioned poor corporate governance, among other factors as responsible for corporate failures and bankruptcies in Ghana. When companies failed or collapse, ordinary shareholders are the most affected. In this case their value maximization would become a mirage. The World Bank in its corporate governance country assessment publication (World Bank, 2005) reported that Ghana has recently to some extent improved its corporate governance regulation. Therefore with this improvement in corporate governance regulation in Ghana, to what extent is it influencing shareholder value maximization?

The purpose of this study therefore is to examine the relationship between corporate governance and shareholder value maximization of the listed companies in Ghana.

\section{Review of relevant literature}

Corporate governance is concerned with the processes and structures through which members interested in the overall well-being of the firm take measures to protect the interests of the stakeholders. Good corporate governance is centered on the principles of accountability, transparency, fairness and responsibility in the management of the firm. The institution of corporate governance in a firm is an attempt to ensure the separation of ownership and control, and this often results in principal-agent problems (Jensen and Meckling, 1976). Agency theory explains the conflict of interests between the shareholders and managers. The separation of ownership and control has been one of the most contentious issues in the financial literature.

Corporate governance structures deal with the ownership structure, such as the proportion of internal and external block holdings. It also deals with the composition of the board of directors, such as the proportion of non-executive directors and the size of the board. In addition, corporate governance mechanisms deal with the independence of the board, and also the possible separation of Chief Executive Officer's (CEO) responsibility from that of the chairperson (Ehikioya, 2009). A welldefined and functioning corporate governance system helps a firm to attract investment, raise funds, and strengthen the foundation for firm performance. Good corporate governance shields a firm from vulnerability to future financial distress. In listed firms, the shareholders are represented by members of the board. The managers are responsible in directing the affairs of the firm. Through the board of directors, the shareholders provide incentives that allow the managers to pursue the interests of those who provide finance and of other stakeholders.

The recent financial turmoil in Asia in the late 1990s and high profile scandals in Enron, WorldCom and other related companies has again stimulated policy makers, investors, academics and other stakeholders, both in the public and private sectors, to take interest in the campaign for good corporate governance. The challenges from these recent events have necessitated the taking of various measures across the globe. These measures, such as the Sarbanes-Oxley Act of 2002, regulate the system to ensure adherence to principles of good corporate governance (Aguilera, 2005).

Corporate governance extends to find a solution to the principal-agent problem. The principal, being the finance provider, is seeking ways to ensure the agent (management) handle their investment in such a way as to guarantee maximum returns for them as investors and other stakeholders. Advocates of corporate governance have identified internal and external governance mechanisms that reduce the agency problem (Agarwal and Knoeber, 1996). The performance of these control mechanisms largely depends on the environment. The corporate governance structure such as ownership structure, board composition, board size, debt, and CEO duality have a great influence on performance. Documentary evidence suggests that the relationship between corporate governance structure and firm performance can 
either be positive (Morck et al., 1989), negative (Lehman and Weigand, 2000), or nuetral (Bolton and von Thadden, 1998).

Studies on corporate governance have identified two basic corporate ownership structures: concentrated and dispersed. In most developed economies, the ownership structure is highly dispersed. However, in developing countries where there is a weak legal system to protect the interests of the investors, the ownership structure is highly concentrated. According to La Porta et al. (1999) ownership concentration is a response to differing degrees of legal protection of minority shareholders across countries. A highly concentrated ownership structure tends to create more pressure on management to engage in activities that maximize investors and other stakeholders' interests.

\section{Empirical study on corporate board}

Research on the impact of corporate board has grown significantly but with mixed results. While the study by Wen et al. (2002) found a negative relationship between the number of outside directors on the board and performance, Bhagat and Black (2002) found no relationship between outside directors and Tobin's Q. The Tobin's Q is defined as the ratio of the market value of assets to book value of assets. In another related work, the proportion of outside directors was found to have a significant positive relationship to firm performance (Brickley et al., 1994).

Lipton and Lorsch (1992) were the first to hypothesize that board size affects corporate governance. The underlying notion is that at some point the coordination problems outweigh the advantages from having more people to draw on. Jensen (1993) notes that "when boards get beyond seven or eight people, they are less likely to function effectively and are easier for the CEO to control". Yermack (1996) presents empirical support for this proposition. Using a sample of large US public corporations, he reports an inverse association between board size and firm valuation. This finding is not necessarily clear ex ante; an alternative hypothesis could be that larger boards bring together specialists from various functional areas and therefore contribute to higher firm values. However, his results are robust to a variety of control variables, such as company size, growth opportunities and ownership structure. He carefully accounts for possible endogeneity problems. Causality runs from board size to firm valuation, and there is no evidence that companies change board size as a result of past performance. Specifically, the results are inconsistent with the conjecture that board size increases after poor performance in an attempt to increase management capacity. Yermack (1996) also reports that smaller boards are more likely to dismiss CEOs for poor performance, and that CEO compensation is less dependent on performance if board size increases.

Huther (1997) analyzes the relationship between board size and operating costs of US electricity companies. He also reports a negative board size effect. Nevertheless, because the possible endogeneity of board size is not properly taken into account, his results must be interpreted with due care. Conyon and Peck (1998) test the board size effect for a sample of firms from the United Kingdom, France, the Netherlands, Denmark, and Italy. Their results show a negative relationship between board size and firm valuation and the return on equity, respectively. However, the statistical significance is rather mixed. In a related study for a sample of Dutch firms, Postma, van Ees and Sterken (2003) report a negative relationship between board size and the market-to-book ratio, but again they do not properly account for the endogeneity problem.

Eisenberg, Sundgren and Wells (1998) find a negative relationship between board size and firm valuation for a sample of small Finnish firms. The average number of board members is 3.7 in their sample, as compared to 12.25 in Yermack (1996). This is interesting because average board size in their sample is significantly below the 
"critical" number of board members of about 7 or 8 , which has been put forth by Lipton and Lorsch (1992) and Jensen (1993). Taken together, the results are clearly inconsistent with the existence of an optimal board size. To avoid biased estimates in ordinary least square regressions in the presence of endogeneity, Eisenberg, Sundgren and Wells (1998) test a simultaneous system of two equations, modeling board size and return on assets as the dependent variables. However, while this is an appropriate methodology, they do not account for possible relationships between different governance mechanisms.

Finally, Loderer and Peyer (2002) analyze the effects of board overlap and seat accumulation on share prices for a panel of Swiss firms. They report that seat accumulation is negatively related to firm value. Board size is used as a control variable in pooled regressions. Their results document that larger board size is associated with lower firm valuation.

\section{Corporate governance and firm attributes}

Within an agency framework, a number of firm attributes have been tested for their association with governance quality, but overall with no more conclusive results. For example, better-governed firms could be more profitable today; investors could expect higher future profitability; they could make better investments; or investors could value the same earnings (or dividends) more highly. Effective corporate governance ensures also, in some cases, the optimal use of resources both intra- and inter-firm. With effective systems of corporate governance debt and equity capital will go to these corporations that are capable of investing it in the most efficient manner for the production of highly demanded goods and services (Khanchel, 2007).

\section{Effective corporate governance: External financing needs and growth opportunities}

The quality of governance may be related to external financing. La Porta et al., (1998) argued that greater investor protection increases investors' willingness to provide financing and should be reflected in lower costs and greater availability of external financing. This shows that firms with the greatest needs for financing in the future will find it the most beneficial to adopt better governance mechanisms today. Moreover, firms with good growth opportunities will need to raise external financing in order to expand and may therefore find it optimal to improve their governance mechanisms as better governance and better minority shareholder protection will be likely to lower their costs of capital (La Porta et al., 1999; Himmelberg et al., 2002). So if more external financing results in profitable investment opportunities, firms with greater external financing are likely to have better corporate governance (Durnev and Kim, 2005). Demirgu“'c,-Kunt and Maksimovic (1998), however, predict the opposite. They argue that profitable firms have more internally generated funds and hence rely less on external financing.

\section{Effective corporate governance and intangible assets}

According to Himmelberg et al., (1999), the composition of the assets of a firm will also affect its contracting environment because it is easier to monitor and harder to steal fixed assets (i.e. machinery and equipment) than "soft" capital (i.e. intangibles, R\&D capital, and short-term assets, such as inventories). Therefore, firms operating with higher proportions of intangible assets may find it optimal to adopt stricter 
governance mechanisms to signal to investors that they intend to prevent the future misuse of these assets.

\section{Effective corporate governance and investment opportunities}

Some papers argue that better-governed firms can offset myopia and allow managers to make the "long-term" decision to increase R\&D and other capital expenditures (Stein, 1988; 1989). Under this view, good governance would increase capital expenditure, and this increase could have a positive effect on firm value. On the other hand, a long literature dating back at least to Baumol (1959), discusses the motivation of managers to undertake inefficient projects in order to extract private benefits. These problems are particularly severe when managers are entrenched (Jensen and Ruback, 1983; Shleifer and Vishny, 1989). Under this view, investment opportunities rise following the enhancement of governance quality. As a consequence, firms with profitable investment opportunities will have better corporate governance.

\section{Effective corporate governance and firm size}

The effect of firm size on governance is ambiguous as large firms may have greater agency problems (because it is harder to monitor them or because of the "free cash flows" argument of Jensen (1986)) and therefore need to compensate with stricter governance mechanisms. Alternatively, small firms may have better growth opportunities and, as implied by the argument above, greater need for external finance and better governance mechanisms.

\section{Effective corporate governance and firm performance}

Numerous studies have been conducted on the effect of corporate governance on firm value, arriving at conclusions that are very inconclusive. Some of these studies concluded that there is a positive relationship between corporate governance and firm value, whiles others concluded that the relationship that exists between corporate governance and firm value is negative. Yet, another line of conclusion that appears in the literature is that there is no statistically significant relationship between corporate governance and firm value. MacAvoy and Millstein (1999) argue that the mixed results have followed from concentrating on periods when boards were largely irrelevant and using unreliable proxies for board independence. Hermalin and Weisbach (2000) suggest that there is little to suggest that board composition has any cross-sectional relation with firm value.

Numerous studies have suggested that effective corporate governance impacts positively on firm value. Pinkowitz et al., (2006) postulate that firms that choose to use the capital markets of countries with better investor protection are valued more highly and that the associated valuation premiums are inversely related to investor protection in the firm's country. Further, Durnev and Kim (2005) find that firm value is negatively related to proxies for investor protection. The literature further shows that outside investors discount firm assets in countries with poor investor protection to reflect their expectations that they will not receive the full benefit of these assets (Pinkowitz et al., 2006).

Chen (2008) suggests that establishing effective governance mechanisms may in turn effectively enlarge the degree of freedom for firms to make timely business decisions, leading to an improvement in firm value. Dittmar and Mahrt-Smith (2007) show that governance has a substantial impact on firm value through its impact on cash, depending on the measure of governance. The evidence shows that firms with poor corporate governance dissipate cash quickly and in ways that significantly reduce operating performance. This negative impact of large cash holdings on future 
operating performance is cancelled out if the firm is well governed. The literature shows that poorly governed firms dissipate cash through acquisitions thus impacting negatively on firm value. Harford et al., (2008) find that a well governed firm has its excess resources better "fenced in," and that firms with poor corporate governance dissipate excess cash reserves more quickly on less profitable investments than those with good governance. In short, poorly governed firms waste excess cash resources and thus destroy firm value. Gompers et al., (2003) find evidence that firms with stronger shareholder rights have a higher firm value, higher profits, and lower capital expenditures. Brown and Caylor (2006) create a corporate governance index (CGI) based on 51 corporate governance provisions propounded by Institutional Shareholder Services. They find that better-governed firms are associated with higher financial value.

For Russian firms, Black (2001) finds a positive relationship between corporate governance behavior and market performance. Black et al., (2006) create a governance score using a survey conducted by the Korean Stock Exchange and find that firms with higher scores have a higher market value. Cheung et al., (2007) examine the relation between corporate governance and firm value by constructing a corporate governance index, which reflects the presence of good corporate governance practices as well as variation in the quality of corporate governance practices for Hong Kong listed companies and concluded that a company's market valuation is positively related to its overall CGI score, a composite measure of a firm's corporate governance practices. They further conclude that in Hong Kong, good corporate governance practices are consistent with value maximization.

Rosenstein and Wyatt (1990) find a very slight increase in stock prices when a company appointed an additional outside director. MacAvoy and Millstein (1999) find a positive relationship between board independence and financial value. Carter et al., (2003) conclude that boards with both insiders and outsiders produce the best financial value. Baysinger and Butler (1985) test the relationship between the percentage of independent directors and a relative measure of return on equity. They find that boards with more outsiders outperformed other firms but that a majority of independent directors was not necessary to insure above average value.

Agrawal and Knoeber (1996) find a negative relation between the proportion of outside directors and firm performance among the US firms. They posit that a political process within firms influences the selection of outside directors, and the directors may be less effective as they are beholden through the selection process. Shrader et al., (1997) investigate the relationship between the percentage of female board members and financial value and find a significant negative relationship between the percentage of women on the board and firm value. Jensen (1986) argues that entrenched managers - left unmonitored - may waste free cash flows.

Nevertheless, another group of studies also suggest that there exist no significant relationship between corporate governance and firm value. Bhagat and Black (1999) investigate the US firms and find no significant relation between board independence and long-term firm performance. Klein (1998) finds no association between a firm's committee structure and firm value. An earlier study, also conducted by Bhagat and Black (1999) also finds no relationship between long-term market returns and board independence. Hermalin and Weisbach (1991) compared the percentage of outsiders on boards to a relative measure of Tobin's Q. They conclude that there is no relationship between the percentage of outsiders on the board and firm value. Zahra and Stanton (1988) use canonical analysis to test the relationship between the percentage of ethnic minority directors and firm value but found no statistically significant relationship.

In theory, good corporate governance should be related to high-corporate valuation. A number of empirical studies have found that investors are willing to pay a premium averaging 10-12 percent for good corporate governance (Khanchel, 2007). The 
correlation of the governance index with performance could be explained in several different ways. One explanation, suggested by the results of other studies, is that inefficient governance directly causes additional agency costs. If the market estimates these additional costs, then stock returns will drop (Khanchel, 2007). An alternative explanation is that good governance is a signal or symptom of lower agency costs - a signal not properly incorporated in market prices. Each of these explanations has different economic implications for the source of agency problems and different policy implications for the regulation of governance.

\section{Effective corporate governance and institutional ownership}

The role that the institutional investors can play in the corporate governance system of a company is a controversial question. Some studies show that the institutional investors must interfere in the corporate governance system of a company. The result of these studies shows that if the corporate governance system in the companies succeeds, then the institutional investors must play an active role in the entire process. For example, Shleifer and Vishny (1986) observe that institutional investors by virtue of their large stockholdings would have greater incentives to monitor corporate performance since they derive greater benefits from monitoring. Cremers and Nair (2005) argue that some institutional investors such as pension funds might have more incentives to monitor than others and act as more aggressive shareholder activists.

Other studies find that institutional investors need not play a role in the corporate governance system of a company. For example, Wharton et al., (1991) argue that institutional investors need not take active interest in the corporate governance of a company because the institutional investors have their primary fiduciary responsibility for their own investors and beneficiaries, which can lead to a conflict of interest with their acting as owners. For instance, Monks (1995) has argued that absence of appropriate incentives and free rider problems hinder institutional activism efforts.

Some recent research, however, shows that companies with good governance system have actually generated risk-adjusted excess returns for their shareholders and hence, if an institutional investor invests in companies with good corporate governance records, it will actually help its own shareholders. Ajinkya et al., (1999) found a positive relationship between financial analysts' ratings of corporate disclosure practices and institutional stock ownership. Overall, it is not clear from the current literature how the institutional ownership affects the strength of monitoring. However, the literature suggests that the nature of these institutional investors might be important in determining their willingness to monitor.

\section{Effective corporate governance and managerial ownership}

Jensen and Meckling (1976) argue that the agency problems can be minimized when managers have an ownership interest in the company. This convergence-of-interest model maintains that the interests of management and shareholders become more aligned and the incentive to indulge in opportunistic behavior diminishes as the proportion of equity owned by insiders increases. In this area, insiders and managers and directors who, in addition to being shareholders, also participate in the decisionmaking process. In this context, a large body of literature suggests that, for most companies, managerial ownership helps executives make better decisions, which enhances corporate governance quality. For example, Lewellen et al., (1985) and Loderer and Martin (1997) show that when executives have larger ownership stakes, acquisition decisions are received more positively by the market. 
Although increased managerial ownership could indicate the presence of managerial entrenchment, it has been argued that managers could indulge in opportunistic behavior which is contrary to shareholders' interests. However, this opportunistic behaviour can be minimized if firm adopt certain governance characteristics relating to incentive and monitoring mechanisms (i.e. strong governance).

\section{The origins of "shareholder value"}

The arguments in support of governing corporations to create shareholder value came into their own in the United States in the 1980s (Lazonick and O'Sullivan, 2000). As has been the case throughout the twentieth century, in the 1980 s a relatively small number of giant corporations employing tens or even hundreds of thousands of people dominated the economy of the United States. On the basis of capabilities that had been accumulated over decades, these corporations generated huge revenues. They allocated these revenues according to a corporate governance principle that we call "retain and reinvest". These corporations tended to retain both the money that they earned and the people whom they employed, and they reinvested in physical capital and complementary human resources. Retentions in the forms of earnings and capital consumption allowances provided the financial foundations for corporate growth, while the building of managerial organizations to develop and utilize productive resources enabled investments in plant, equipment and personnel to succeed (Corbett and Jenkinson 1996).

As, during the 1970s, major US manufacturing corporations struggled with these very real problems of excessive centralization and innovative competition, a group of American financial economists developed an approach to corporate governance known as agency theory. Trained, as virtually all American economists are, to believe that the market is always superior to organizations in the efficient allocation of resources, these economists were ideologically predisposed against corporate - that is, managerial - control over the allocation of resources and returns in the economy. Agency theorists posited that, in the governance of corporations, shareholders were the principals and managers were their agents.

Agency theorists also argued that, because corporate managers were undisciplined by the market mechanism, they would opportunistically use their control over the allocation of corporate resources and returns to line their own pockets, or at least to pursue objectives that were contrary to the interests of shareholders. Given the entrenchment of incumbent corporate managers and the relatively poor performance of their companies in the 1970s, agency theorists argued that there was a need for a takeover market that, functioning as a market for corporate control, could discipline managers whose companies performed poorly. The rate of return on corporate stock was their measure of superior performance, and the maximization of shareholder value became their creed (Ross, 1973; Jensen and Meckling, 1976; Fama and Jensen, 1983; Jensen, 1986).

In addition, during the 1970s, the quest for shareholder value in the US economy found support from a new source - the institutional investor. The transfer of stockholding from individual households to institutions such as mutual funds, pension funds and life insurance companies made possible the takeovers advocated by agency theorists and gave shareholders much more collective power to influence the yields and market values of the corporate stocks they held (Lazonick and O'Sullivan, 2000). During the 1950s and 1960s, there were legal restrictions on the extent to which life insurance companies and pension funds could include corporate equities in their investment portfolios, while mutual funds played only a limited, although growing, role in the mobilization of household savings.

In the 1970s, however, a number of changes occurred in the financial sector that promoted the growth of equity-based institutional investing. Partly as a consequence 
of Wall Street's role in the buying and selling of companies during the conglomeration mania of the 1960s, from the early 1970s there was a shift in the focus of Wall Street financial firms from supporting long-term investment activities of corporations (mainly through bond issues) to generating fees and capital gains through trading in corporate and government securities. To expand the market for securities trading, Wall Street firms convinced the Securities and Exchange Commission (SEC) to put an end to fixed commissions on stock exchange transactions. At the same time, developments in computer technology made it possible for these firms to handle much higher volumes of trade than had previously been the case.

\section{Size of the board}

Jensen (1993) and Lipton and Lorsch (1992) have argued that large boards are less effective and are easier for a CEO to control. Raheja (2005) showed that larger boards have higher coordination costs. Also smaller boards reduce the possibility of free riding by individual directors and thus increase their decision-making processes - a fact supported by empirical research.

The number of board of directors is assumed to have an influence on corporate decision. The board is vested with responsibility for managing the firm and its activities. There is no agreement over whether a large or small board does this better. Yermack (1996) suggests that the smaller the board of directors the better the firm's performance. Eisenberg et al., (1998) find a negative relationship between board size and profitability when studying a sample of small and mid-sized Finnish firms. Mak and Yuanto (2003) also confirmed the above findings in firms listed in Singapore and Malaysia when they found that firms are highly valued by using board membership of five directors; a number considered relatively small in those markets. Some empirical studies have found a positive relationship between small-sized boards and corporate performance (Sanda et al., 2005). Yermack (1996) further argued that larger boards are found to be slow in decision making.

The monitoring expenses and poor communication in a larger board has also been seen as a reason for the support of small board size (Lipton and Lorsch, 1992; and Jensen, 1993). However, there is another school of thought that believes that firms with larger board size have the ability to push the managers to pursue lower costs of debt and increase performance (Anderson et al., 2004). Studies by Wen et al., (2002) and Abor (2007) both reported evidence in support of a positive relationship between board size and leverage. They argued that large boards with superior monitoring ability pursue higher leverage to raise the value of the firm.

Shareholders are represented by the Board of Directors, and other stakeholders usually find ways to control the activities of the management to ensure value maximization. One such move is to compel the managers to secure debt financing from financial institutions (Ehikioya, 2009).

Financial institutions such as banks have the skills and other resources to control the activities of firms, thereby serving as a useful tool for minimizing the principal-agent conflict. Financial institutions take a special interest in seeing that the management of firms where they have relationship takes measures that will improve the performance of the firm. For example, Shleifer and Vishny (1997) citing the work of Kaplan and Minton (1994), found a higher incidence of management turnover in one of the developed countries in response to poor firm performance. Mir and Nishat (2004) found that high leverage gave an adverse signal about the performance of the firm, Ahuja and Majumdar (1998) found a positive relationship between the levels of debt of the firm and performance. They concluded that a higher debt is related to higher firm performance. 


\section{Board independence}

John and Senbet (1998) showed that the independence of a corporate board is measured by the number of outside or non-executive directors (NEDs), the more independent the board. Thus, the larger proportion of non-executive directors, the more independent the board is. Baysinger and Butler (1985) and Rosenstein and Wyatt (1990) have also shown that the market rewards firms for appointing outside directors. A general consensus however is that non-executive directors are deemed to act as "professional referees" to ensure shareholder value maximization (Fama, 1980). Thus, the appointment of NEDs enhances firm performance (Brickley and James, 1987; Weisbach, 1988; Brickley et al., 1994). Other empirical studies have found no significant relationship between board independence and performance (Hermalin and Weisbach, 1991; Yermack, 1996; Bhagat and Black, 2002).

The composition of the board may be used to ameliorate the principal-agent problem. The participation of outside directors is designed to enhance the ability of the firm to protect itself against threats from the environment and align the firm's resources for greater advantage. However, research on the impact of outside directors has grown significantly but with mixed results. Firms with higher number of outside directors are expected to pursue activities that would bring about low financial leverage with a high market value of equity (Baysinger and Butler, 1985).

\section{CEO duality}

Should a CEO double as board chairman? Considerable attention has been given to the role of boards in monitoring managers and in removing non-performing CEO's Jensen (1993) voices a concern that a lack of independent leadership makes it difficult for boards to respond to failure in top management team. It has been noted though, that when a CEO doubles as board chairman, it leads to leadership facing conflict of interests and increasing agency costs (Brickley et al., 1997). Largely, studies have shown that the separation of the two positions enhances shareholders' value (Kyereboah-Coleman, 2007b).

Several studies have examined the separation of CEO and chairperson/vice chairperson position, a situation that is predominantly found in an environment with a weak legal system. It is widely argued that the principal-agent problem is more obvious in a business environment where the same person holds the positions of CEO and chairperson (vice chairperson). CEO duality has a way of influencing the overall performance of the firm. The rationale for the separation of CEO and chairperson's position was first suggested by Fama and Jensen (1983). Yermack (1996) reported that firms are more valuable when the CEO and chairperson's positions are held separately. A series of checks and balances are instituted in firms where there is no CEO duality and this prevents the agent from indulging in opportunistic behaviour.

The expectation of the present study is that firms with small board size, high board independence and without CEO duality are likely to enhance shareholder value by making a decision that would ensure higher dividend yield to shareholders and therefore shareholders having confidence in the board.

\section{Methodology}

\section{Research design}

This study mainly had an explanatory research purpose since it aims to establish the effect of corporate governance variables on shareholder value maximization. The study adopted a case study approach (i.e. Ghana Stock Exchange as a case). A case study methodology is a preferred research approach where the research question to 
be addressed is a type of how-why; control of the researcher over the research is none or very insignificant and the focus is on a contemporary phenomenon. Because of these differentiating characteristics, no approach could have answered and achieved the research questions and objectives respectively than the case research method. In the case study methodology, the focus is not on a limited number of predetermined independent variables, but on factors, which are helpful in explaining the observed phenomena. This study adopted a deductive approach as it is based on existing literature and theories. The empirical data gathered were only compared to the existing theories and conclusions drawn. The quantitative approach was adopted in establishing the impact of board size, board independence and CEO duality on shareholder value maximization

\section{Sample and data}

The study sampled ten companies through convenience sampling. Convenience sample are widely used because of ease of obtaining data. The companies are included in the sample on the basis of data availability and with due regard to year of operation. Also they are companies that express desire to answer the questionnaires on governance variables. However, almost all the category of companies was part of the sample. The firms include Accra Brewery Company Ltd., Aluworks Limited, Cocoa Processing Co. Ltd., Enterprise Insurance Co. Ltd., Fan Milk Ltd., Ghana Commercial Bank Ltd., Mechanical Llyod Co. Ltd., Produce Buying Company Ltd., Super Paper Products Co. Ltd. and Unilever Ghana Ltd.

The study used annual data covering a five-year period (2003 - 2007). The data comprise financial data and corporate governance variables. For the financial data, the Ghana Stock Exchange fact books served as the main sources of the data and governance variables data was obtained through both the company's annual reports and the Ghana Stock Exchange fact books. Therefore the study used secondary data.

\section{Research variables description and justification}

Some studies have looked at corporate governance and firm performance and others have looked at corporate governance and investors' protection by essentially looking at legal and accountability issues related to firms. While some have contended that the creation of value by enhancing the performance of a firm indirectly ensures shareholder value maximization, Kyereboah-Coleman (2007a) counter such argument and advance the point that the performance of a firm may not necessarily impact on shareholder wealth. This study shares the view of Kyereboah-Coleman and measure shareholder value by looking at dividend yield (DYIELD) and dividend per share (DPS) as the dependent variables. Certainly, the dividend yield is a popular direct measurable benefit that accrues to shareholders. The study measure dividend yield as the ratio of total dividend paid to common shareholder to the market value of the common stock at the beginning of the year. And dividend per share is ratio of total dividend pay-out to total shares.

With regard to the independent variables, the study capture size of the board (BOARDSIZE), the independence of the board (BOARDIND) and whether the CEO doubles as board chairman or otherwise (DUALROLE). Board size is measured as the total number of directors sitting on the board. Board independence is measured as the ratio of non-executive directors to the total number of board size (John and Senbet, 1998). The duality of the CEO is measured as dummy variable with a value of 1 when a CEO doubles as the board chair and 0 if otherwise.

Due to the recognition that the researcher is inadequately equipped to model shareholder value maximization, the study capture firms specific characteristics as such firm size (measured by total asset), asset tangibility (measured by ratio of fixed 
assets to total assets), leverage (measured by the ratio of total debts to total assets) and firm age, as possible control variables. In carrying out this study, due recognition have been given to the fact that corporate governance involves a set of complex indicators which face substantial measurement error. It would therefore be appropriate to have had a broader set of indicators. However, due primarily to data limitations, we have employed governance indicators such as board size, board independence, CEO duality, as corporate governance variables. Therefore the expectation of this study was that corporate governance would enhance shareholder value maximization.

\section{Data analysis model}

The analysis was carried out within a panel data framework, basically because of panel character of the data and its advantage of allowing for a broader set of data points. Panel data involve the pooling of observations on a cross-section of units over several time periods and facilitate identification of effects that are simply not detectable in pure cross-sections or pure time-series studies. The panel regression equation differs from a regular time-series or cross section regression by the double subscript attached to each variable. The use of panel data helps to take into account the heterogeneity of firms in relation to possible explanatory variables (Ehikioya, 2009). The general form of the panel data ordinary least square (OLS) regression model is defined by the following equation:

$$
Y_{i t}=\alpha+b X_{i t}+\ddot{e}_{i t}
$$

The subscript $i$ represent the cross-sectional dimension and $t$ denoting the time-series dimension. The left-hand variable $Y_{i t}$, represents the dependent variable in the model, which is the shareholder's value. $X_{i t}$ contains the set of independent variables in the estimation model, $\alpha$ is taken to be constant over time $t$ and specific to the individual cross-sectional unit $i$. If $\alpha$ is taken to be the same across units, Ordinary Least Squares (OLS) provides a consistent and efficient estimates of $\alpha$ and $B$. The study adopted a model used by Kyereboah-Coleman (2007b) with some modification. The model takes the following form:

$$
\begin{gathered}
D P S_{i, t}=B_{0}+B_{1} \text { BOARDSIZE }_{i, t}+B_{2} \text { BOARDIND }_{i, t}+B_{3} \text { DUALROLE }_{i, t}+ \\
{ }_{4} \text { LEV }_{i, t}+b_{5} \text { SIZE }_{i, t}+b_{6} \text { TANG }_{i, t}+b_{7} A G E_{i, t}+e_{i t}
\end{gathered}
$$

$$
\begin{gathered}
\text { DYIELD }{ }_{i, t}=B_{0}+B_{1} \text { BOARDSIZE }_{i, t}+B_{2} \text { BOARDIND }_{i, t}+B_{3} \text { DUALROLE }_{i, t}+ \\
{ }_{4} \text { LEV }_{i, t}+b_{5} \text { SIZE }_{i, t}+b_{6} \text { TANG }_{i, t}+b_{7} A G E_{i, t}+e_{i t}
\end{gathered}
$$

where:

DYIELD $D_{i, t}=$ ratio of total dividend paid to common shareholder to the market value of the common stock for firm $i$ in period $t$;

$D P S_{i, t}=$ ratio of total dividend pay-out to total shares to firm $i$ in period $t$

$B O A R D S I Z E_{i, t}=$ the total number of directors sitting on the board

-13 -

International Cross-Industry Journal 
$B O A R D I N D_{i, t}=$ ratio of independent members to the total number of directors

$D U A L R O L E_{i, t}=$ Dual role

$L E V_{i t}$, = ratio of total debts to total assets for firm $i$ in period $t$;

$S I Z E_{i t}=\log$ of total assets for firm $i$ in period $t$;

$T A N G_{i, t}=$ ratio of fixed assets to total assets for firm $i$ in period $t$;

$A G E_{i, t}=$ age of firm $i$ in period $t$;

$\ddot{\mathrm{e}}_{i t}=$ the error term.

\section{Regression analysis model}

The effect of corporate governance on shareholder wealth maximization was tested using the panel data methodology. Specifically, estimates were obtained for the following equations:

$$
\begin{aligned}
& D P S_{i, t}=b_{0}+b_{1} B_{O A R D S I Z E_{i, t}}+b_{2} \text { BOARDIND }_{i, t}+b_{3} \text { DUALROLE }_{i, t}+e_{i t} \\
& D P S_{i, t}=B_{0}+B_{1} B_{\text {OARDSIZE }}+B_{i, t} \text { BOARDIND }_{i, t}+B_{3} \text { DUALROLE }_{i, t}+b_{4} L E V_{i, t}+ \\
& B_{5} S_{I Z E_{i, t}}+B_{6} T_{A N G}+B_{i, t} A G E_{i, t}+e_{i t} \\
& D P S_{i, t}=B_{0}+b_{1} B_{O A R D S I Z E_{i, t}}+b_{2} L E V_{i, t}+b_{3} T A N G_{i, t}+b_{4} A G E_{i, t}+e_{i t}
\end{aligned}
$$

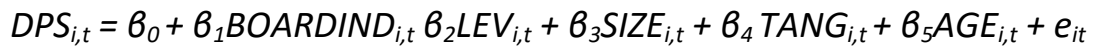

$$
\begin{aligned}
& D P S_{i, t}=B_{0}+b_{1} D U A L R O L E_{i, t} B_{2} L E V_{i, t}+B_{3} \operatorname{SIZE}_{i, t}+b_{4} T A N G_{i, t}+b_{5} A G E_{i, t}+e_{i t} \\
& \text { DYIELD } D_{i, t}=b_{0}+b_{1} \text { BOARDSIZE }_{i, t}+b_{2} \text { BOARDIND }_{i, t}+b_{3} \text { DUALROLE }_{i, t}+e_{i t}
\end{aligned}
$$

Where DPS is dividend per share, DYIELD is dividend yield, BOARDSIZE is size of the board members, BOARDIND is independence of the board, DUALROLE is CEO duality, $L E V$ is firm leverage, SIZE is size of the firm, TANG is asset tangibility and $A G E$ is age of the firm.

\section{Analysis and discussion}

The Table 1 shows a summary of the descriptive statistics of the variables computed from the financial statements and the annual reports of sampled firms on the Ghana Stock Exchange. From the table, the mean dividend yield was 0.0247 . This indicated that, on average a shareholder on the Ghana Stock Exchange expects to gain $2.5 \%$ in exchange for buying a given stock, ignoring any capital gain that may arise. The minimum and maximum values also showed that within the period under 
consideration some shareholders were not paid dividend at all, while others also, within the period under study, got $11 \%$ dividend yield. The mean dividend per share was $2.26 \%$. This is supported by minimum value of 0 and a maximum of $10.5 \%$.

\section{TABLE 1. SUMMARY OF DESCRIPTIVE STATISTICS}

\begin{tabular}{|c|c|c|c|c|c|}
\hline Variable & Obs & Mean & Std. Dev. & Min & $\operatorname{Max}$ \\
\hline------- & ---- & -------- & --------- & ---- & ------- \\
\hline DYIELD & 50 & .024716 & .0283027 & 0 & .11 \\
\hline DPS & 50 & .022648 & .029571 & 0 & .105 \\
\hline BSIZE & 50 & 8.2 & 1.665986 & 5 & 12 \\
\hline BOARDIND & 50 & .78302 & .142783 & .4 & .9 \\
\hline DUALITY & 50 & .02 & .1414214 & 0 & 1 \\
\hline LEV & 50 & .60907 & 1.005214 & 0 & 4.9 \\
\hline TANG & 50 & .34138 & .2428676 & .013 & .904 \\
\hline AGE & 50 & 31.68 & 10.86549 & 11 & 54 \\
\hline SIZE & 50 & 7.414394 & .6038329 & 6.145275 & 8.39561 \\
\hline
\end{tabular}

Source: Ghana Stock Exchange Fact Book, 2003 - 2008.

The mean board size is 8.2 (i. e. eight), with a maximum of twelve board of directors and a minimum of five board of directors. This observation is in line with Lipton and Lorsch (1992) recommendation. They suggested an optimal board size of between seven and nine directors. This may suggest that Ghanaian listed firms have board size that conforms to Lipton and Lorsch recommendation. The mean board independence is 0.78 . This suggests that for the sampled firms about $22 \%$ of the boards of directors are made up of executive directors (i.e. those that are part of the management team). This seems to suggest that firms on the Ghana Stock Exchange have boards which are highly independent as they are dominated by non-executive directors. However, some of these boards are relatively less independent with $40 \%$ of their membership being constituted of non-executive directors (not part of the management).

Abor (2007) reported that in Ghana, the companies' code and the stock exchange listing requirements do not stipulate the composition of corporate board membership. There are no requirements to distinguish between executive and nonexecutive directors. The appointment of executive and non-executive directors is the prerogative of the firm. Another observation is separation of board chairperson and CEO personalities. Only one occasion out of the fifty observations was the CEO and the board chair positions entrusted to the same personality. This value represents $2 \%$. With this, one may tend to suggest that agency problem may not be major issues among the Ghanaian listed firms as suggested by Berg and Smith (1978) and Brickley et al., (1997) that when a CEO doubles as board chairman, it leads to leadership facing conflict of interests and therefore increasing agency costs.

The variable LEV measures the ratio of debt to book value of equity. This indicates the firms' level of debt in relation to their owners' equity. The average value of this variable is 0.61 . This suggests that Ghanaian firms listed on the Ghana Stock Exchange are financially highly geared, with maximum of 4.9 during the period under review. This shows that most firms depend on debt for their operations. From the descriptive statistics, most of the firms have a relatively more current assets than fixed assets with a mean value of 34\% representing asset tangibility. Most of the firms' studied have been operating for about 32 years. Nevertheless, there is a wide variation between the ages of these firms as shown in the standard deviation of 10.9. To check the size of the firm and its relationship with shareholder wealth maximization, natural logarithm of total asset is used as a control variable. The mean value of log of total asset is 7.41 while the standard deviation is 0.6. The maximum value of log of total asset for a company in a year is 8.39 and the minimum is 6.14 . 


\section{Correlation analysis}

The Table 2 and Table 3 show the correlation of the covariates. From Table 2 it can be observed that there is a slightly weak correlation between the dependent variables and the six covariates: board size, board independence, CEO duality, leverage, asset tangibility, age and size of the firm. The dividend yield has negative correlations with board independence, leverage, asset tangibility and age but has positive correlations with board size, CEO duality and size of the firm. From Table 3 the dividend per share exhibits negative correlations with board independence, leverage and age, but positive correlation with board size, CEO duality, asset tangibility and size of the firms. The highest correlation among the covariates was the correlation between board size and size of the firm and is positive. The value is $55.23 \%$. The positive correlation seems to suggest that, large firms tend to have large board size. The lowest correlation among the covariates was between the board size and the age of the firm. The value is $4 \%$.

After using more than one variable to examine the contribution of independent variables to the regression model, it may be suggested that there is a multicollinearity problem among these variables. Thus, a multicollinearity test is carried out to assess the degree of correlation among variables. Pearson's correlation is employed to observe correlations among the independent variables.

TABLE 2. CORRELATION OF COVARIATES

\begin{tabular}{|c|c|c|c|c|c|c|c|c|c|}
\hline & I & dyield & bsize & boardind & duality & lev & tang & age & size \\
\hline dyield & 1 & 1.0000 & & & & & & & \\
\hline bsize & 1 & 0.1858 & 1.0000 & & & & & & \\
\hline boardind & 1 & -0.4463 & -0.1762 & 1.0000 & & & & & \\
\hline duality & I & 0.1799 & 0.1559 & -0.3871 & 1.0000 & & & & \\
\hline lev & 1 & -0.2173 & 0.1849 & 0.3197 & -0.0817 & 1.0000 & & & \\
\hline tang & I & -0.0972 & -0.4042 & -0.0652 & 0.1026 & -0.2797 & 1.0000 & & \\
\hline age & 1 & -0.0112 & -0.0437 & 0.2652 & -0.2747 & -0.2370 & -0.0967 & 1.0000 & \\
\hline size & I & 0.1836 & 0.5523 & -0.2030 & 0.1303 & 0.3330 & -0.3023 & -0.2215 & 1.0000 \\
\hline
\end{tabular}

Source: Ghana Stock Exchange Fact Book, 2003 - 2008.

TABLE 3. CORRELATION OF COVARIATES

\begin{tabular}{|c|c|c|c|c|c|c|c|c|c|}
\hline & I & dps & bsize & boardind & duality & lev & tang & age & size \\
\hline dps & I & 1.0000 & & & & & & & \\
\hline bsize & 1 & 0.3360 & 1.0000 & & & & & & \\
\hline boardind & I & -0.7207 & -0.1762 & 1.0000 & & & & & \\
\hline duality & I & 0.3267 & 0.1559 & -0.3871 & 1.0000 & & & & \\
\hline lev & I & -0.3043 & 0.1849 & 0.3197 & -0.0817 & 1.0000 & & & \\
\hline tang & । & 0.0295 & -0.4042 & -0.0652 & 0.1026 & -0.2797 & 1.0000 & & \\
\hline age & I & -0.2069 & -0.0437 & 0.2652 & -0.2747 & -0.2370 & -0.0967 & 1.0000 & \\
\hline size & I & 0.3836 & 0.5523 & -0.2030 & 0.1303 & 0.3330 & -0.3023 & -0.2215 & 1.0000 \\
\hline
\end{tabular}

Source: Ghana Stock Exchange Fact Book, 2003 - 2008. 
Table 2 and Table 3 revealed the correlation coefficients between the independent variables. The "rules of thumb" test, suggested by Anderson et al. (1990), says that any correlation coefficient exceeding 0.7 indicates a potential problem. An examination of the results of correlations presented in Table 2 and 4.3 suggests that there is no problem of multicollinearity among the independent variables.

\section{Regression analysis}

\section{Regression result of dividend per share}

The result of the regression model 2 is shown in Table 4. The model shows the interaction between dividend per share variable as dependent variable and corporate governance variables as independent variable. From the table, the $\mathrm{R}^{2}$ in the regression model indicates that $71.64 \%$ of the variation in dividend per share is explained by the independent variables in the model. The F-statistics (prob > chi 2) prove the efficiency of the estimated models at 0.05 level of significance and the value 0.0000 .

TABLE 4. REGRESSION MODEL RESULT (MODEL 2)

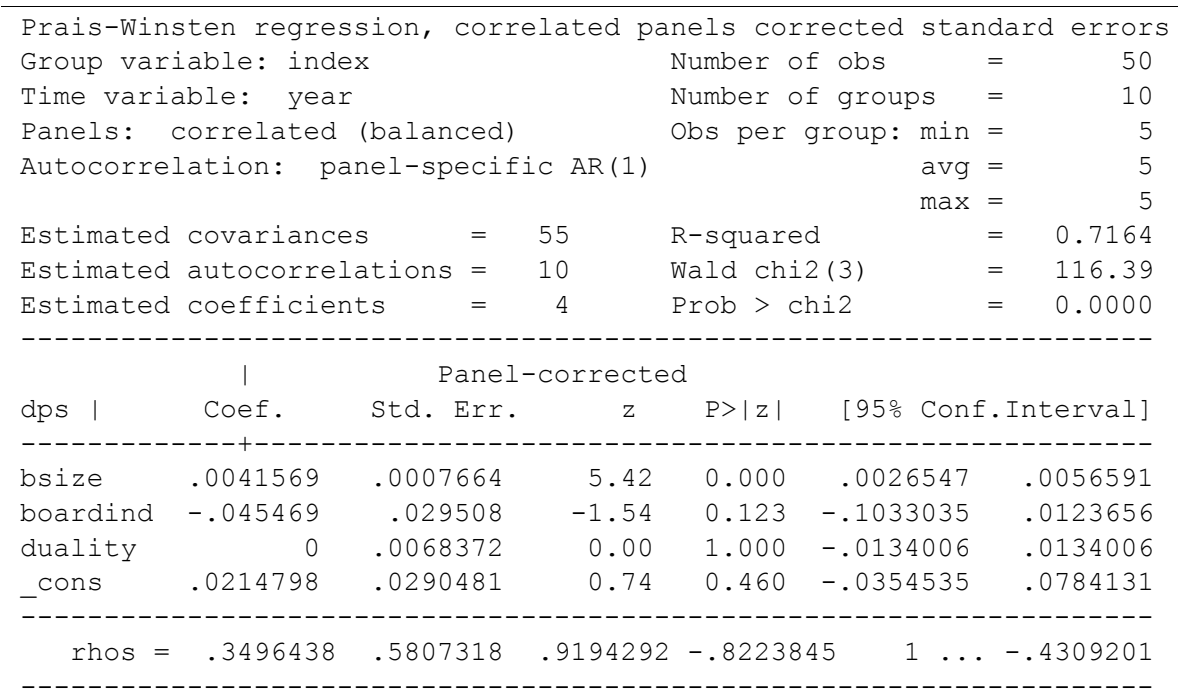

Source: Ghana Stock Exchange Fact Book, 2003 - 2008.

Table 4 shows that the size of the board relates positively and statically significant with the dividend per share. This means that large board size leads to high dividend per share (high dividend payment). This may enhance shareholder value maximization. The positive relation is similar to study by Kyereboah-Coleman, (2007b) but rather contrary to studies by Jensen (1993), Lipton and Lorsch (1992), Mak and Yuanto (2003), Yermack (1996), Eisenberg et al. (1998) and Sanda et al. (2005). However, as indicated by Kyereboah-Coleman (2007b) it could be explained that the presence of large board sizes affords corporate entities the opportunity to enjoy the depth and experience a large pool could bring to bear on its operations. This inevitably enhances firms' performance and promotes shareholder value maximization. The magnitude of the coefficient of the board size variable implies that an increase in the number of board size by 1 member is associated with an increase in shareholder wealth by $0.42 \%$.

The outcome concerning the board independence shows a negatively related but statistically insignificant with the dividend per share. This implied that the -17 - 
independence of the board do not enhance shareholder value maximization. The possible explanation for this observation is that such people are not conversant with operations of the firm and therefore cannot make decisions that are likely to enhance the performance of the firms and therefore shareholder wealth. The negative relation is similar to the findings of Kyereboah-Coleman (2007b). However, the finding is contrary to Rosenstein and Wyatt (1990), Weisbach (1988), Byrd and Hickman (1992), Brickley et al. (1994) who showed that the independent of the board enhances a firms' worth and shareholder value. On the effect of CEO duality on shareholder value maximization, the result as shown in the Table 4 indicates that CEO duality has no effect. Therefore this outcome may be spurious.

Table 5 presents the result of model 3 . Here the $\mathrm{R}^{2}$ is $62.79 \%$ and the F-statistics (prob $>$ chi 2) prove the efficiency of the estimated models at 0.05 level of significance and the value 0.0000 .

TABLE 5. REGRESSION MODEL RESULT (MODEL 3)

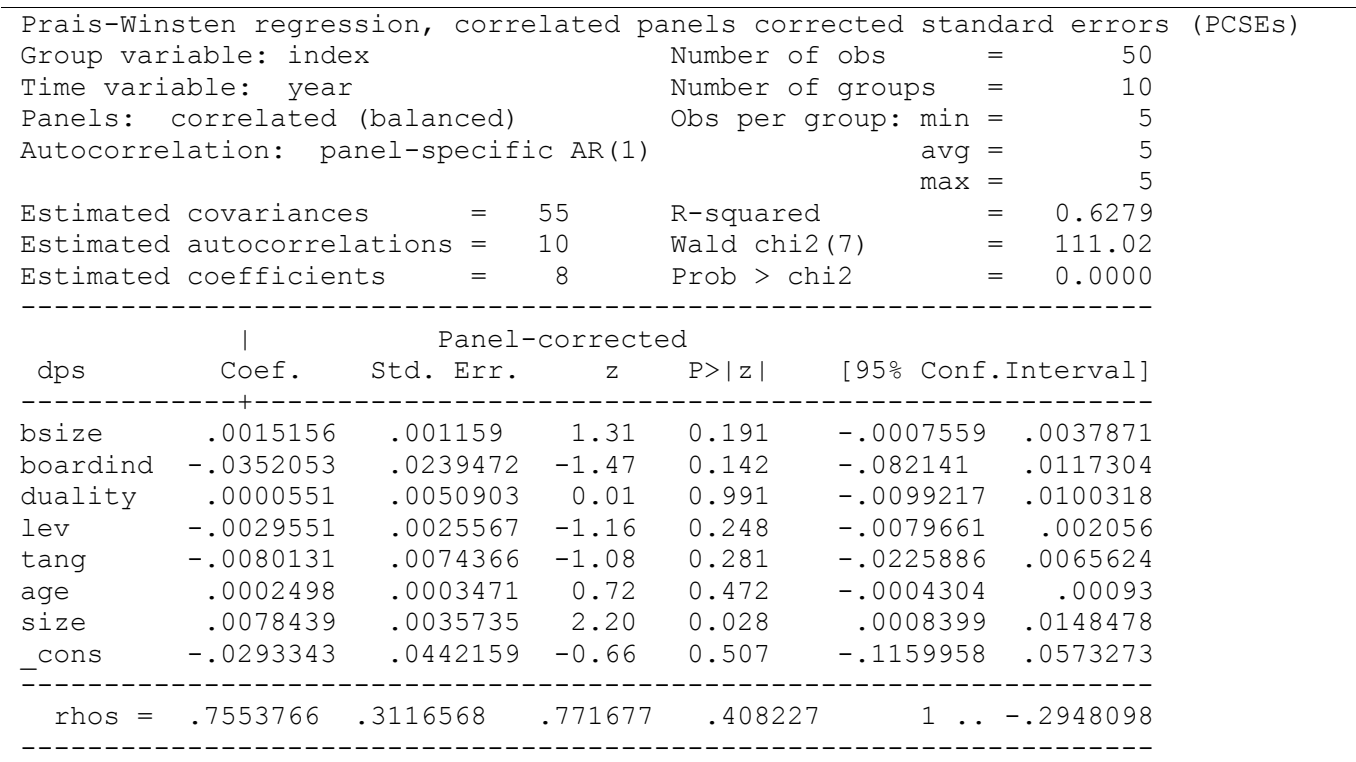

Source: Ghana Stock Exchange Fact Book, 2003 - 2008.

To establish the effect of each of the control variables on the shareholder wealth maximization, the control variables together with the governance variables were regressed with the dividend per share. Table 5 shows the outcome in detail. The outcome of the control variables in the model (3) shows a varied signs with the dividend per share. There is a negative relationship between leverage and dividend per share. This is in line with expectation and consistent to the findings of KyereboahColeman (2007b). However, relationship is statistically insignificant. The negative relationship implies that when a firm employed more debt as part of its capital structure, dividend per share reduces and therefore minimizes shareholder wealth. Asset tangibility showed a negative relationship with dividend per share (shareholder value maximization) but the association is statistically insignificant. This implies that the tangible asset of the firms does not translate into shareholder value maximization. 
TABLE 6. REGRESSION MODEL RESULT (MODEL 4)

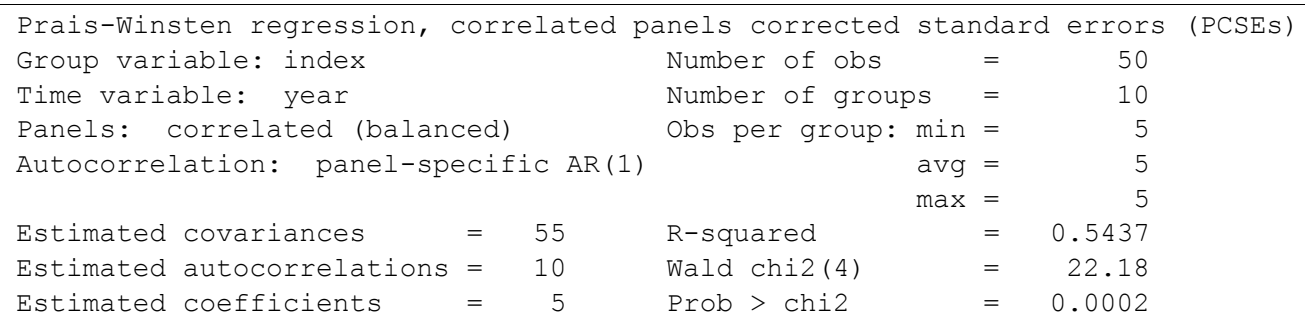

Panel-corrected

\begin{tabular}{|c|c|c|c|c|c|c|}
\hline dps | & Coef. & Std. Err. & z & $P>|z|$ & [95\% Conf. & Interval] \\
\hline ize & .0038371 & .0016565 & 2.32 & 0.021 & .0005903 & .0070838 \\
\hline & -.0055758 & .0027928 & -2.00 & 0.046 & -.0110496 & -.0001019 \\
\hline & .0048824 & .0077868 & 0.63 & 0.531 & -.0103794 & .0201442 \\
\hline & .0000652 & .0003344 & 0.19 & 0.845 & -.0005903 & .0007206 \\
\hline ns & -.0114978 & .0097504 & -1.18 & 0.238 & -.0306083 & .0076127 \\
\hline & & & & & & \\
\hline & .7516213 & .5331255 & 728650 & -.2549 & 1 & .2581 \\
\hline
\end{tabular}

Source: Ghana Stock Exchange Fact Book, 2003 - 2008.

The age of the firms which served as a proxy for reputation related positively with dividend per share. This observation is in line to expectation. Firms that have been operated for long period have certain reputation in term of enhancing their shareholder wealth. Size of the firm showed the expected sign. The size of the firm related positively with dividend per share and the relationship is statistically significant. This implied that large firms tend to show good performance and therefore pay high dividend which in turn enhance shareholder value maximization.

\section{TABLE 7. REGRESSION MODEL RESULT (MODEL 5)}

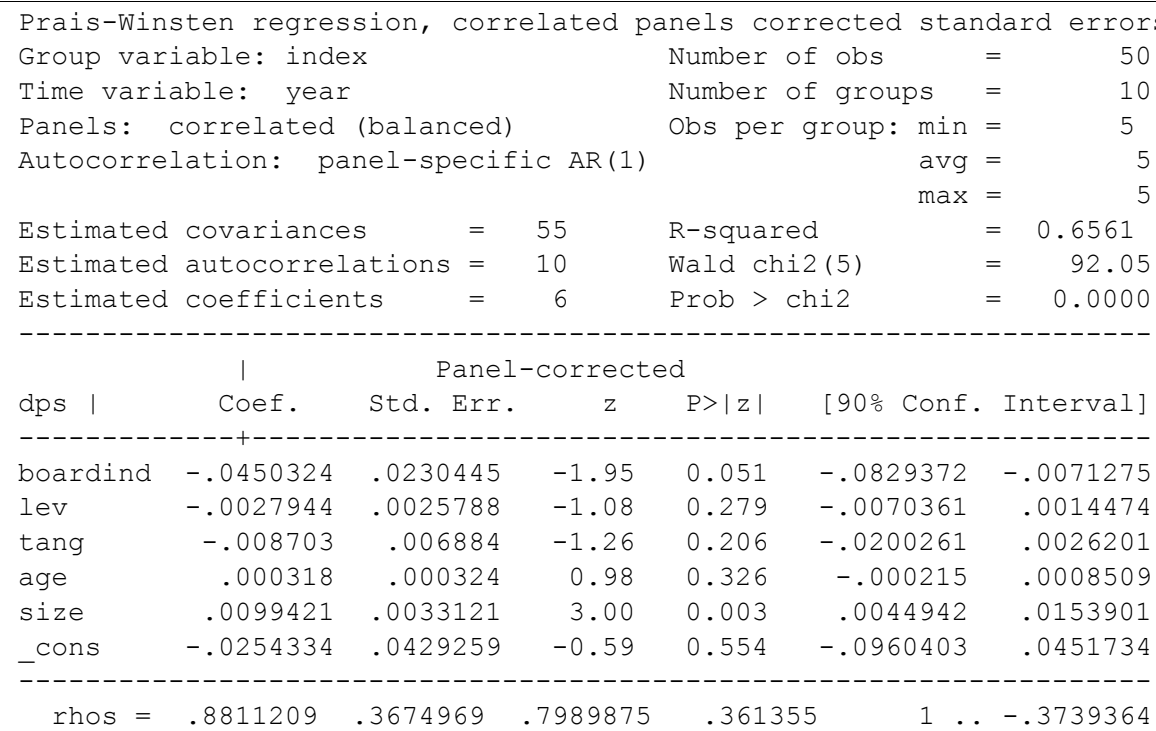

Source: Ghana Stock Exchange Fact Book, 2003 - 2008. 
Another observation about the outcome of regression model (3) is the significant effect of board size. From Table 5 board size is statistically insignificant. This might be as a result of multicollinearity. To establish the role of each governance variable to shareholder wealth maximization, regression model (4), (5) and (6) were regressed. Table 6 , Table 7 and Table 8 present the results in details. Table 6 presents the result of model 4. The model shows the interaction between dividend per share as dependent variable and corporate board size as independent variable together with firm leverage, asset tangibility and firm age as a control variable. The $R^{2}$ in the model is $54.37 \%$ and the F-statistics (prob > chi 2) prove the efficiency of the estimated models at 0.05 level of significance and the value 0.0002 .

TABLE 8. REGRESSION MODEL RESULt (MODEL 6)

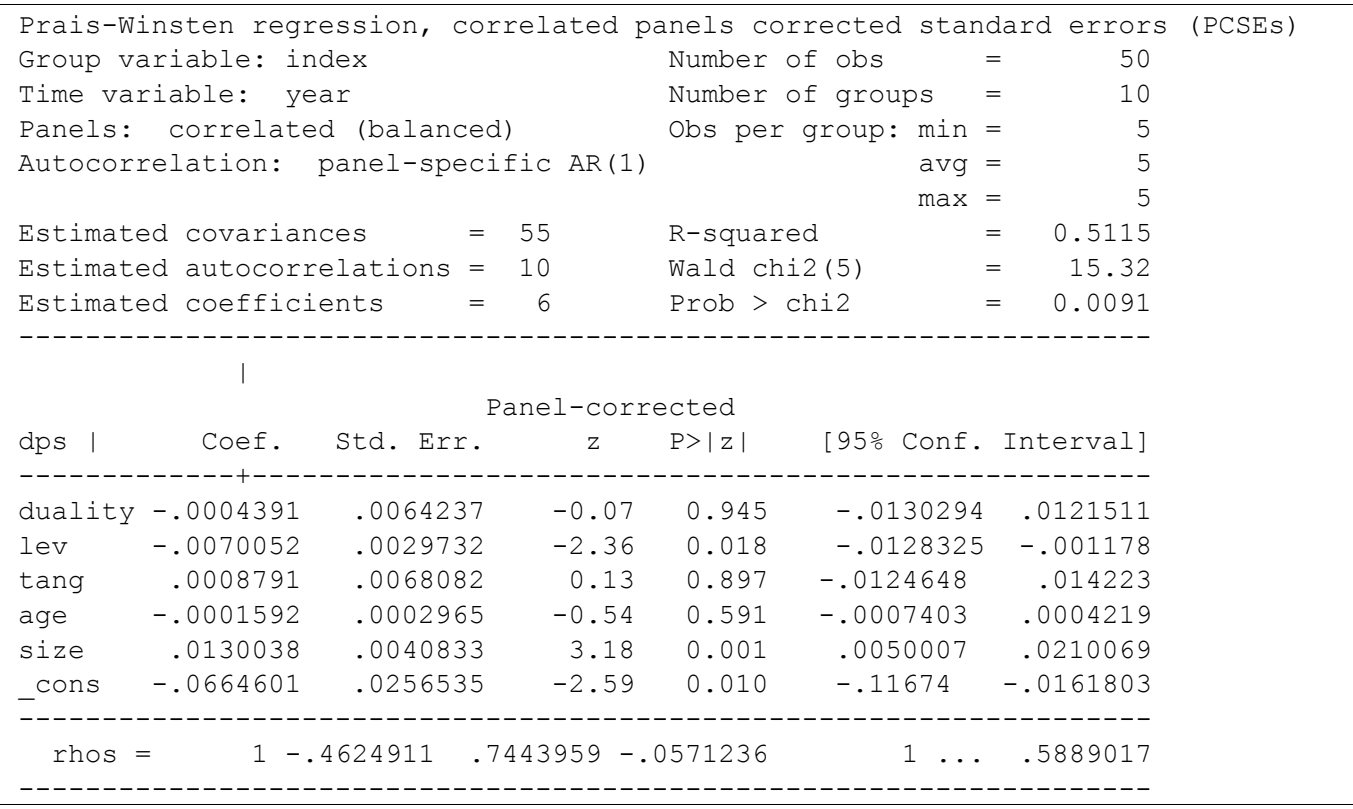

Source: Ghana Stock Exchange Fact Book, 2003 - 2008.

From Table 6, board size is statistically significant and positively related to shareholder wealth maximization. This confirms that the insignificant effect might be due to multicollinearity. Firm leverage shows a significant negative relation with shareholder wealth maximization. Table 7 presents the interaction between dividend per share as dependent variable and board independence as independent variable. Firm size, firm leverage, asset tangibility and firm age were added to the model as control variable. The $\mathrm{R}^{2}$ in the model (5) is $65.61 \%$ and the F-statistics (prob > chi 2) prove the efficiency of the estimated models at 0.1 level of significance and the value 0.0000. The board independence in the model related negatively to dividend per share and the relationship is statistically significant at $90 \%$ confidence level $(0.1$ level of significant). Table 6 shows the result in detail.

Table 8 presents the result of model (6). The $R^{2}$ in the model is $51.51 \%$ and the Fstatistics (prob > chi 2) prove the efficiency of the estimated models at 0.05 level of significance and the value 0.0091 . However, the result of CEO duality influence on shareholder wealth maximization shows a negative relation. Table 8 shows the result in detail. The negative relation confirms the spuriousness nature of the effect of CEO duality. 
Regression result of dividend yield

Table 9 presents the result of regression model 7. The model shows the interaction between dividend yield as dependent variable and corporate governance variables as independent variable. The $\mathrm{R}^{2}$ in the model is $39.7547 \%$ and the F-statistics (prob > chi 2 ) prove the efficiency of the estimated models at 0.05 level of significance and the value 0.0000 .

\section{TABLE 9. REGRESSION MODEL RESULT (MODEL 7)}

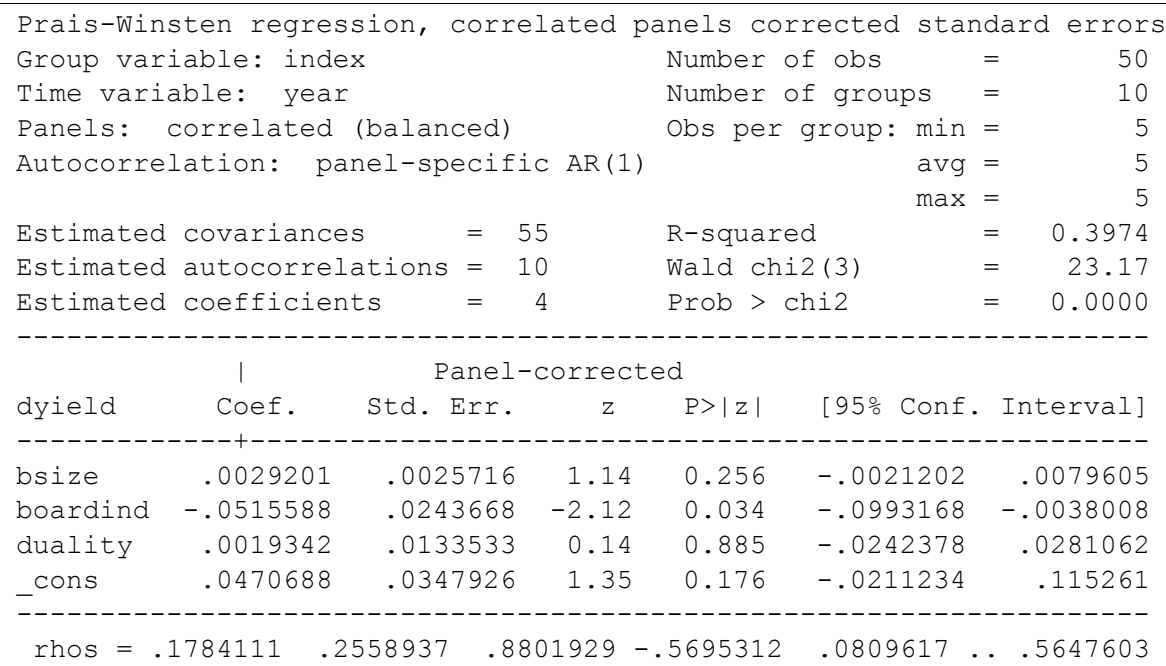

Source: Ghana Stock Exchange Fact Book, 2003 - 2008.

As a robustness check of how corporate governance variables influence shareholder value maximization, dividend yield was regressed with the corporate governance variables as shown in model 7. The result is indicated in Table 9. The board size shows the positive relation but the relationship is statistically insignificant with dividend yield. The board independence related negatively with the dividend yield. Here, the relationship is statistically significant at $95 \%$ confidence level. The board independence in the regression model has a magnitude of coefficient of -0.052 . This value implied that a unit change in board independence will reduce shareholder value by $5.2 \%$. In the case of CEO duality, the sign of the coefficient is positive but it is statistically insignificant. The positive relations between CEO duality and dividend yield confirm the inconclusive nature of the effect of CEO duality on shareholder maximization.

Among the governance variables, board size and the board independence show the significant effects with shareholder wealth maximization. Also the variable with greater influence on shareholder wealth maximization is board independence since it is the one with higher magnitude of coefficient in the models.

\section{Summary of findings}

From Table 1 the mean dividend yield was 0.0247 . This indicates that on average, shareholders expect to gain $2.5 \%$ in exchange for buying a given stock, ignoring any capital gain that may arise. The minimum and maximum values for the dividend yield were between zero and eleven per cent. The mean dividend per share was $2.26 \%$. This was supported by minimum value of 0 and a maximum of $10.5 \%$. The board size has a mean value of eight with a maximum of twelve board members and a minimum -21 - 
of five. This observation is in line with Lipton and Lorsch (1992) recommendation. The mean board independence is 0.78 . This suggests that for the sampled firms about $22 \%$ of the boards of directors are made up of executive directors (i.e. those that are part of the management team). However, some of these boards are relatively less independent with $40 \%$ of their membership being constituted of non-executive directors. During the period under review, only one occasion out of the fifty observations was the CEO and the board chair positions entrusted to the same personality. This value represents $2 \%$. The mean debt ratio was 0.61 indicating that more than half of the capital employed by the firms is made up of debt. The descriptive statistics shows that most of the firms have a relatively more current assets than fixed assets with a mean value of $34 \%$ been tangible asset. On the average, the firms' understudies have been operating for about 32 years

\section{Effect of board size on shareholder value maximization}

The analysis of the empirical data carried out revealed that board size relate positively with all the variable of shareholder wealth maximization (dividend per share and dividend yield). However, the relationship is statistically significant with dividend per share while in the case of dividend yield the relationship is statistically insignificant. The positive relationship between board size and all shareholder wealth maximization suggests that larger boards adopt policy that ensure high dividend payment and therefore enhance the value of the shareholder wealth.

\section{Effect of board independence on shareholder value maximization}

The regression analysis outcome indicated the board independence is negatively related with all the variable of shareholder value maximization (dividend per share and dividend yield). This implied that the independence of the board does not ensure that policies are adopted to enhance shareholder value maximization. However, the relationship is statistically significant at $95 \%$ confidence level in the case of dividend yield whiles in the case of dividend per share it is statistically significant at $90 \%$ confidence level.

\section{Effect of CEO duality on shareholder value maximization}

The outcome concerning CEO duality, the results show negative with dividend per share and positive in the case of dividend yield. This makes the CEO duality effect on shareholder wealth maximization inconclusive.

\section{Effect of firm leverage on shareholder value maximization}

Firm leverage relate negatively with shareholder value maximization. The negative relationship implies that when a firm employed more debt as part of its capital structure, dividend per share reduces and therefore minimizes shareholder wealth.

\section{Effect of firm size on shareholder maximization}

The size of the firm related positively with shareholder value maximization. In the case of dividend per share the relationship is statistically significant while it is insignificant with dividend yield. This implied that large firms tend to show good performance and therefore pay high dividend which in turn enhance shareholder value maximization. The size of the firm in the regression model 2 has a magnitude of 
the coefficient of 0.00784 . This value implied that a unit change in firm size will increase shareholder value by $0.78 \%$.

\section{Conclusion}

The study seeks to examine how corporate governance influence shareholder wealth maximization of firms listed on Ghana Stock Exchange. Three key corporate governance variables were considered: board size, board independence and CEO duality. These three variables were study because they were argued to be important in influence shareholder wealth maximization.

The findings show that both the board size and the independence have statistically significant relationship with shareholder wealth maximization. While the relationship is positive with the board size, it is negative in the case of board independence. However, in the case of CEO duality, the result is spurious and therefore inconclusive.

Moreover, the composition of Ghanaian boards appears to be consistent with the international practices where the majority of the members are outsiders and the size of the boards is also about eight. Firms that were sampled having their CEO also as chair of the board constitute 2 per cent.

Generally, a well-established corporate governance system suggests effective control and accounting systems, stringent monitoring, effective regulatory mechanism and efficient utilization of firms' resources resulting in improved performance. Firms with well-established corporate governance structures are able to developed structure and policy that would ensure shareholder value maximization.

\section{Recommendations}

The study has produced some interesting results and one avenue for future research is to extend the investigation to other emerging markets, especially those in the sub region. The incentives for further research on other emerging markets come from the limitation of the studies which currently exist. Further research that will replicate these studies using more comprehensive governance variable such board activity intensity, CEO tenure from Ghana would shed more light on issues raised in this study.

As a follow up to the study the following recommendation is made to be considered by the firms on the Ghana Stock Exchange:

- In order to enhance shareholder wealth maximization, firms may have to increase or not reduce their current board size. A relatively larger board size puts pressure on managers, through stringent monitoring and regulatory mechanism, to pursue policies that will enhance shareholders wealth.

- To enhance the shareholder wealth of the firms listed on the GSE, the independence of the corporate board should be minimal as more independence according to outcome of the study reduces shareholder wealth.

- Listed firms that wish to enhance shareholder wealth maximization should reduce the level of debt finance.

- Investors and potential investors should buy shares in large companies on the GSE since the study established that shareholders of large companies earn more dividends. 


\section{References}

Abdullah S.N., 2004. "Board composition, CEO duality and performance among Malaysian listed companies", Corporate Governance, Vol.4, No.4, pp.47-61

Abor J., 2007. "Corporate governance and financing decisions of Ghanaian listed firms", Corporate Governance: International Journal of Business in Society, Vol.22, No.1, pp.83-92

Agarwal A. and Knoeber C., 1996. "Firm performance and mechanism to control agency problems between managers and shareholders", Journal of Financial and Quantitative Analysis, Vol.31, No.3, pp.377-97

Aguilera, R.V., 2005. "Corporate governance and director accountability: an institutional comparative perspective", British Journal of Management, Vol.16, No.1, pp.1-15

Ahuja G. and Majumdar, S., 1998. "An assessment of the performance of Indian state-owned enterprises", Journal of Productivity Analysis, Vol.9, No.2, pp.113-32

Ajinkya B., Bhojraj S. and Sengupta P., 1999. "The effect of corporate governance on disclosure", working paper, University of Florida, Gainesville, FL

Anderson R., Mansi S. and Reeb D., 2004. "Board characteristics, accounting report integrity and the cost of debt", Journal of Accounting and Economics, Vol.37, No.3, pp.315-42

Baumol W.J., 1959. Business Behavior, Value and Growth, Macmillan, New York, NY

Baysinger B.D. and Butler H.N., 1985. "Corporate governance and board of directors performance effects of changes in board composition", Journal of Law Economics and Organization, Vol.1, No.1, pp.101-24

Bhagat, S. and Black, B., 1999. "The uncertain relationship between board composition and firm value", Business Lawyer, Vol.54, pp.921-63

Bhagat S. and Black B., 2002. "The non-correlation between board independence and long term firm performance", Journal of Corporation Law, Vol.27, No.2, pp.231-74

Black B., 2001. "The corporate governance behavior and market value of Russian firms", Emerging Markets Review, Vol.2, pp.89-108

Black B., H. Jang and Kim W., 2003. 'Does Corporate Governance Affect Firm Value?', Working Paper 327, Stanford Law School

Black B.S., Jang H. and Kim W., 2006. "Does corporate governance predict firms' market values? Evidence from Korea", Journal of Law, Economics, and Organization, Vol.22, pp.366413

Bolton, P. and von Thadden, E., 1998. "Blocks, liquidity and corporate control", Journal of Finance, Vol.53 No.1, pp.1-25

Brealey R.A. and Myers S.C., 2002. Principles of Corporate Finance, 7th edition, McGrawHill/Irwin, London

Brickley J.A. and James C.M., 1987. "The Takeover Market, Corporate Board Composition, and Ownership Structure: The Case of Banking", Journal of Law and Economics, Vol.30, pp.16181

Brickley J.A., Jeffrey L.C. and Rory L., 1994. "Outside directors and the adoption of poison pills", Journal of Financial Economies, Vol.35 No.3, pp.371-90

Brickley J.A., J.L. Coles and Jarrell G., 1997. "Leadership Structure: Separating the CEO and Chairman of the Board", Journal of Corporate Finance, Vol.3, No.3, pp.189-220

Brown L. and Caylor M., 2006. "Corporate governance and firm operating performance", Journal of Accounting and Public Policy, Vol.25, pp.409-34

Carter D., Simkins B. and Simpson W., 2003. "Corporate governance, board diversity and firm value", The Financial Review, Vol.38, pp.33-53

Chen Y., 2008. "Corporate governance and cash holdings: listed new economy versus old economy firms", Corporate Governance, Vol.16 No.5, pp.430-42

Cheung Y.L., Connelly J.T., Limpaphayom P. and Zhou L., 2007. "Do investors really value corporate governance? Evidence from the Hong Kong market", Journal of International Financial Management and Accounting, Vol.18 No.2, pp.86-122

Conyon M. and Peck I. S., 1998. "Board Size and Corporate Performance: Evidence from European Countries", European Journal of Finance. 4: 291-304

Corbett J. and Jenkinson T., 1996. "The financing of industry, 1970-1989: an international comparison", Journal of the Japanese and International Economies, Vol.10, No.1, pp.71-96 
Cremers K.J.M. and Nair V.B., 2005. "Governance mechanisms and equity prices", Journal of Finance, Vol.60, No.6, pp.2859-94

Demirgu"c -Kunt, A. and Maksimovic V., 1998. "Law, finance, and firm growth", Journal of Finance, Vol.53, No.6, pp.2107-37

Dittmar A. and Mahrt-Smith J., 2007. "Corporate governance and the value of cash holdings", Journal of Financial Economics, Vol.83, pp.599-634

Dufrene U. and Wong A., 1996. "Stakeholders Versus Stockholder and Financial Ethics: Ethics to Whom?", Managerial Finance, Vol.22, pp.1- 10

Durnev A. and Kim E.H., 2005. "To steal or not to steal: firm attributes, legal environment, and valuation", Journal of Finance, Vol.60, pp.1461-93

Ehikioya B.I., 2009. "Corporate governance structure and firm performance in developing economies: evidence from Nigeria", Corporate governance, Vol.9, No.3, pp.231-243

Eisenberg T., Sundgren S. and Wells M.T., 1998. 'Larger Board Size and Decreasing Firm Value in Small Firms', Journal of Financial Economics, Vol.48, No.1, pp.35-54

Fama E.F., 1980. "Agency problems and the theory of the firm", Journal of Political Economy, Vol.88, No.2, pp.288-307

Fama E. and Jensen M., 1983. "Separation of ownership and control", Journal of Law and Economics, Vol.26, No.2, pp.301-25

Gompers P., L. Ishii and A. Metrick, 2003. "Corporate Governance and Equity Prices", Quarterly Journal of Economics, Vol.118, pp.107- 55

Harford J., Mansi S.A. and Maxwell W.F., 2008. "Corporate governance and cash holdings", Journal of Financial Economics, Vol.87, No.3, pp.535-55

Hermalin B.E. and Weisbach M.S., 1991. "The effects of board composition and direct incentives and firm performance", Financial Management, Vol.20, pp.101-12

Hermalin B.E. and Weisbach M.S., 2000. "Boards of directors as an endogenously determined institution: a survey of the economic literature", working paper, University of California, Berkeley, CA

Himmelberg C.P., Hubbard R.G. and Love I., 2002. "Investor protection, ownership and the cost of capital", Working Paper, No.2834, World Bank Policy Research, Washington, DC

Huther J., 1997. "An Empirical Test of the Effect of Board Size on Firm Efficiency", Economics Letters. Vol.54, pp.259-264

Jensen M.C. and Meckling W.H., 1976. "Theory of the firm: managerial behaviour, agency costs and capital structures", Journal of Financial Economics, Vol.3, No.4, pp.305-60

Jensen M.C., 1986. "Agency costs of the free cash flow, corporate finance and takeovers", American Economic Review, Vol.76, pp.323-9

Jensen M. C., 1993. "The Modern Industrial Revolution, Exit, and the Failure of Internal Control Systems", Journal of Finance, Vol.48, pp.831-880

Jensen M. and Ruback R., 1983. "The market for corporate control: the scientific evidence", Journal of Financial Economics, Vol.11, Nos 1/4, pp.5-50

John K. and Senbet L.W., 1998. "Corporate Governance and Board Effectiveness", Journal of Banking and Finance, Vol.22, pp.371-403

Kaplan S. and Minton B., 1994. "Appointment of outsiders to Japanese boards: Determinants and implications for managers", Journal of Financial Economics, Vol.36, No.2, pp.225-57.

Khanchel I., 2007. "Corporate governance: measurement and determinant analysis", Managerial Auditing Journal, Vol.22, No.8, pp.740-760

Klein A., 1998. "Firm performance and board committee structure", Journal of Law and Economics, Vol.41, pp.275-303

Kyereboah-Coleman A., 2007a. "Relationship between corporate governance and firm performance: An African perspective". PhD thesis (unpublished), pp.84-92

Kyereboah-Coleman A., 2007b. "Corporate Governance and Shareholder Value Maximization: An African Perspective" African Development Review, Vol.19, Issue 2, pp.350-367

La Porta R., Lo'pez-de-Silanes F. and Shleifer A., 1998. "Law and finance", Journal of Political Economy, Vol.106, No.6, pp.113-1155

La Porta, R., Lo'pez-de-Silanes F. and Shleifer A., 1999. “Corporate ownership around the world", Journal of Finance, Vol.54, No.2, pp.471-518 
Lazonick W. and O'Sullivan M., 2000. “Maximizing shareholder value: a new ideology for corporate governance", Economy and Society Vol.29, No.1, pp.13-35

Lehman E. and Weigand J., 2000. "Does the governed corporation perform better? Governance structure and corporate performance in Germany", European Finance Review, Vol.4, No.2, pp.157-95

Lewellen W., Loderer C. and Rosenfeld A., 1985. "Merger decisions and executive stock ownership in acquiring firms", Journal of Accounting and Economics, Vol.7, Nos 1/3, pp.209-31

Lipton M. and Lorsch J.W., 1992. "A modest proposal for improved corporate governance", Business Lawyer, Vol.48, No.1, pp.59-77

Loderer C. and Martin K., 1997. "Executive stock ownership and performance", Journal of Financial Economics, Vol.45, No.2, pp.223-55

Loderer C. and Peyer U., 2002. "Board Overlap, Seat Accumulation and Share Prices", European Financial Management, Vol.8, pp.165-192

MacAvoy P.W. and Millstein I.M., 1999. "The active board of directors and its effect on the value of the large publicly traded corporation", Journal of Applied Corporate Finance,Vol.11, pp.8-20

Mak Y.T. and Yuanto K., 2003. "Board Size Really Matters: Further Evidence on the Negative Relationship between Board Size and Firm Value", Pulses, Singapore Stock Exchange

Mir S. and Nishat M., 2004. "Corporate governance structure and firm performance in Pakistan - an empirical study", presented at the 2nd Annual conference on Corporate Governance, Lahore University of Management Sciences

Monks R.A.G., 1995. Corporate Governance in the Twenty-first Century: A Preliminary Outline, Lens Inc., Washington, DC

Morck R., Shleifer A. and Vishny R., 1989. "Alternative mechanism of corporate control", American Economic Review, Vol.79, No.4, pp.842-52

OECD, 1999. OECD Principles of Corporate Governance, Paris: OECD

Pinkowitz L., Stulz R. and Williamson R., 2006. "Does the contribution of corporate cash holdings and dividends to firm value depend on governance? A cross-country analysis", Journal of Finance, Vol.61, No.6, pp.2725-51

Postma Theo J.B.M., van Ees, H. and Sterken E., 2003. "Board Composition and Firm Performance in the Netherlands", Eastern Economic Journal, Vol.29, pp.41-58

Price Waterhouse Coopers, 2006. "Corporate failures and Bankruptcies in Ghana", Paper delivered at Investment Advocacy Forum, Business House JCR of The University of Ghana, pp.1-38

Raheja C.G., 2005. "Determinants of Board Size and Composition: A Theory of Corporate Boards", Journal of Financial and Quantitative Analysis, Vol.40, No.2, pp.155-60

Rosenstein S. and Wyatt J.G., 1990. "Outside directors, board independence, and shareholder wealth", Journal of Financial Economics, Vol.26, pp.175-91

Ross S., 1973. "The economic theory of agency: the principal's problem", American Economic Review, Vol.63, No.2, pp.134-9

Sanda A.U., A.S. Mukaila and T. Garba, 2005. "Corporate Governance Mechanisms and Firm Financial Performance in Nigeria", AERC Research Paper, No.149

Shrader, B., Blackburn, V.B. and Iles, P., 1997. "Women in management and firm financial value: an exploratory study", Journal of Managerial Issues, Vol.9, pp.355-72

Shleifer A. and Vishny R.W., 1989. "Management entrenchment: the case of manger specific investment", Journal of Financial Economics, Vol.25, No.1, pp.123-40

Stein J.C., 1988. "Takeover threats and managerial myopia", Journal of Political Economy, Vol.96, No.1, pp.61-80

Stein J., 1989. "Efficient capital markets, inefficient firms: a model of myopic corporate behavior", Quarterly Journal of Economics, Vol.104, No.4, pp.655-70

Wen Y., Rwegasira K. and Bilderbeek J., 2002. "Corporate governance and capital structure decisions of Chinese listed firms", Corporate Governance: An International Review, Vol.10, No.2, pp.75-83

Weisbach M.S., 1988. "Outside directors and CEO turnover", Journal of Financial Economics, Vol.20, Nos 1-2, pp.432-60 
Wharton C.G., Lorsch J.W. and Hanson L., 1991. "Rating the corporate governance", Harvard Business Review, November/December

World Bank, 2005. "Ghana Corporate Governance Country Assessment Report", Report on the Observance of Standards and Codes, pp.1-38

Yermack D., 1996. "Higher Market Valuation of Companies with a Small Board of Directors", Journal of Financial Economics, Vol.40, No.2, pp.185-221

Sage Publications

Zahra S.A. and Stanton W.W., 1988. "The implications of board of directors' composition for corporate strategy and value", International Journal of Management, Vol.5, pp.229-36 


\section{Appendix}

\section{APPENDIX 1.CORPORATE GOVERNANCE VARIABLE AND FIRM CHARACTERISTICS DERIVED FROM COMPANIES ANNUAL REPORT}

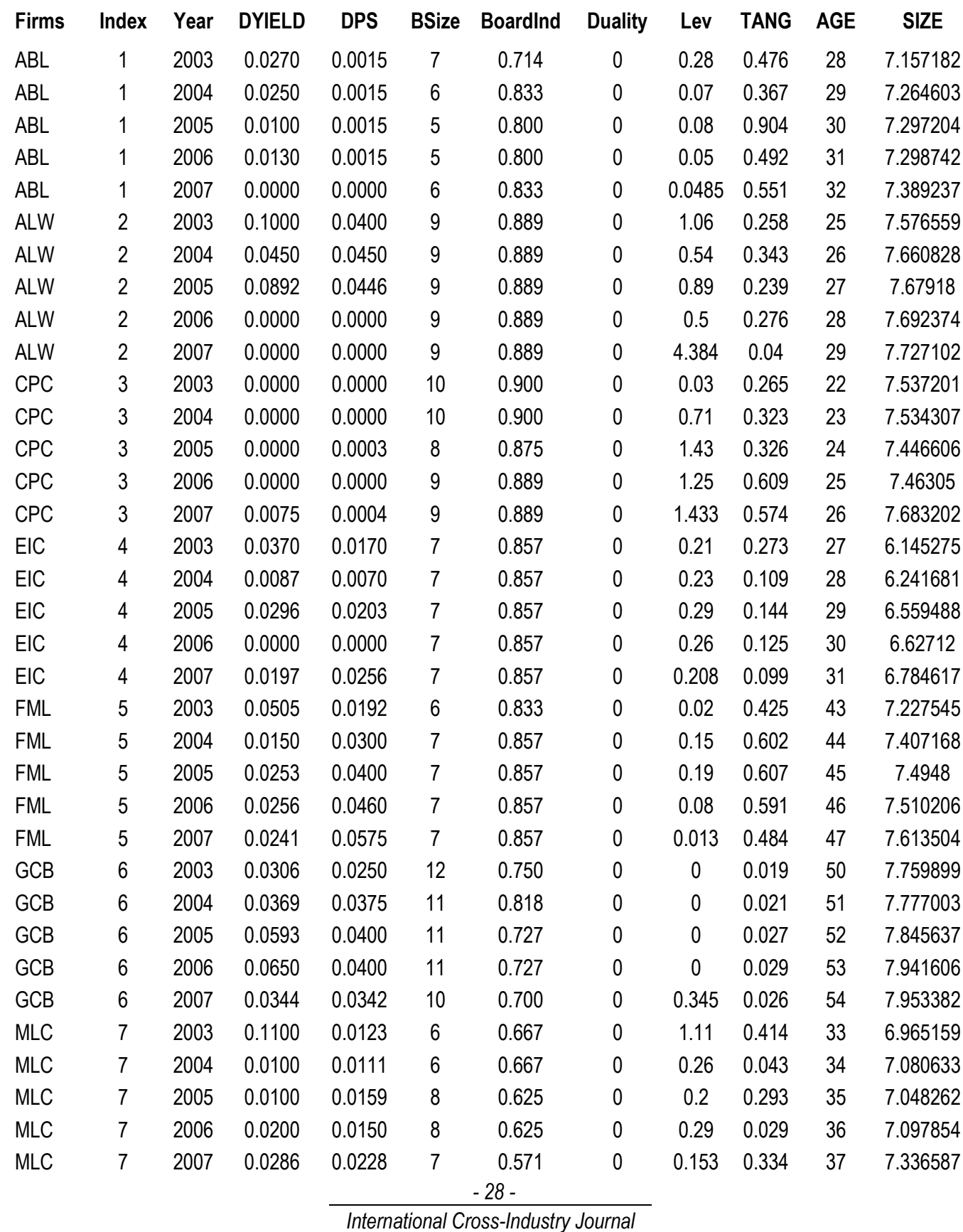




\section{APPENDIX 1.CORPORATE GOVERNANCE VARIABLE AND FIRM CHARACTERISTICS DERIVED FROM COMPANIES ANNUAL REPORT}

$\begin{array}{lccccccccccc}\text { Firms } & \text { Index } & \text { Year } & \text { DYIELD } & \text { DPS } & \text { BSize } & \text { Boardlnd } & \text { Duality } & \text { Lev } & \text { TANG } & \text { AGE } & \text { SIZE } \\ \text { PBC } & 8 & 2003 & 0.0004 & 0.0015 & 9 & 0.889 & 0 & 0.26 & 0.257 & 22 & 8.202815 \\ \text { PBC } & 8 & 2004 & 0.0001 & 0.0025 & 9 & 0.889 & 0 & 1.48 & 0.105 & 23 & 8.361127 \\ \text { PBC } & 8 & 2005 & 0.0000 & 0.0000 & 9 & 0.889 & 0 & 2.35 & 0.102 & 24 & 8.362515 \\ \text { PBC } & 8 & 2006 & 0.0000 & 0.0000 & 8 & 0.875 & 0 & 2.3 & 0.013 & 25 & 8.39561 \\ \text { PBC } & 8 & 2007 & 0.0000 & 0.0000 & 10 & 0.900 & 0 & 4.9 & 0.145 & 26 & 8.290285 \\ \text { SPPC } & 9 & 2003 & 0.0000 & 0.0000 & 8 & 0.875 & 0 & 0.62 & 0.505 & 36 & 6.362537 \\ \text { SPPC } & 9 & 2004 & 0.0000 & 0.0000 & 8 & 0.875 & 0 & 0.76 & 0.456 & 37 & 6.466212 \\ \text { SPPC } & 9 & 2005 & 0.0000 & 0.0000 & 8 & 0.750 & 0 & 0.13 & 0.785 & 38 & 6.383627 \\ \text { SPPC } & 9 & 2006 & 0.0000 & 0.0000 & 6 & 0.833 & 0 & 0.16 & 0.855 & 39 & 6.438515 \\ \text { SPPC } & 9 & 2007 & 0.0000 & 0.0000 & 8 & 0.875 & 0 & 0.088 & 0.809 & 39 & 6.490855 \\ \text { UNIL } & 10 & 2003 & 0.0600 & 0.0896 & 10 & 0.400 & 1 & 0.04 & 0.514 & 11 & 7.959627 \\ \text { UNIL } & 10 & 2004 & 0.0400 & 0.0896 & 10 & 0.400 & 0 & 0.06 & 0.52 & 12 & 7.948467 \\ \text { UNIL } & 10 & 2005 & 0.0600 & 0.0896 & 10 & 0.500 & 0 & 0.23 & 0.497 & 13 & 8.015044 \\ \text { UNIL } & 10 & 2006 & 0.0700 & 0.1050 & 10 & 0.400 & 0 & 0.14 & 0.526 & 14 & 8.074496 \\ \text { UNIL } & 10 & 2007 & 0.0483 & 0.1019 & 8 & 0.500 & 0 & 0.171 & 0.243 & 15 & 8.143183\end{array}$




\section{APPENDIX 2. NORMALITY TEST FOR DIVIDEND YEILD AND DIVIDEND PER SHARE}
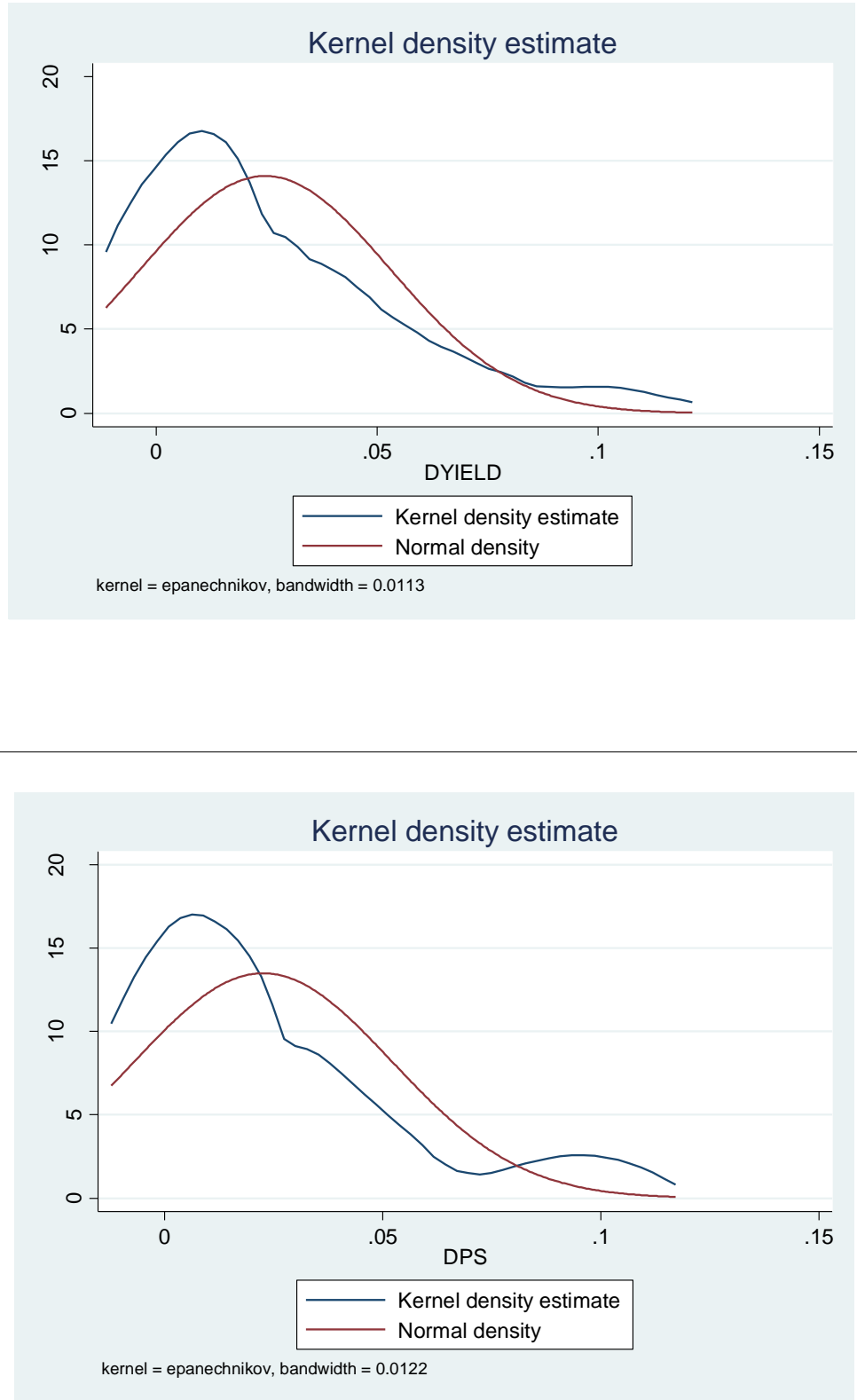